\title{
Cardiac surgery under cardiopulmonary bypass in pregnancy: report of four cases
}

\author{
Youhao You', Shenghua Liu*, Zhaohong Wu'1, Dunjin Chen², Gefei Wang ${ }^{1}$, Gangdong Chen', \\ Youguang Pan ${ }^{1}$ and Xing Zheng ${ }^{1}$
}

\begin{abstract}
Background: Open heart surgery during pregnancy is relatively rare at home and abroad, and there is a higher risk and probability of maternal and infant death. How to carry out heart valve replacement under cardiopulmonary bypass (CPB) under the premise of ensuring the safety of mother and child is the focus of attention at home and abroad.

Case introduction: We reported four cases of cardiac surgeries under CPB during pregnancy performed in our hospital from March 2020 to March 2021. Two of the patients continued their pregnancy after cardiac surgery under CPB. Three patients had infective endocarditis and the other one had an ascending aortic aneurysm. Three patients underwent heart valve placement with the mechanical mitral valve when the other one underwent Bentall surgery. The operations of four cases were all successful, and further follow-up evaluation of the pregnant women and fetuses showed no abnormalities. The patients' detailed information is shown in the following table.
\end{abstract}

Conclusion: Heart disease during pregnancy should be treated actively and proactively when the patient has obvious symptoms. Heart valve replacement under CPB will be the first choice, and this may become the primary surgical treatment for symptomatic heart disease during pregnancy.

Keywords: Heart valve diseases, Cardiac surgical procedure, Cardiopulmonary bypass, Pregnancy, Multidisciplinary team, Perioperative management

\section{Background}

The incidence of heart disease in pregnant women is $1-4 \%$ approximately [1]. Heart disease complicates more than $1 \%$ of pregnancies and accounts for $15 \%$ of maternal mortality, the leading cause of indirect obstetric deaths $[2,3]$. Even in developed countries, the maternal mortality rate has not declined either [2]. Pregnancy is an important factor that aggravates undetected heart disease and makes pregnant women show obvious symptoms. Due to the lack of medical and knowledge and awareness, heart disease in pregnant women is often not

*Correspondence: 455081936@qq.com

1 Thoracic and Cardiovascular Surgery, The Third Affiliated Hospital of Guangzhou Medical University, Guangzhou, Guangdong, China

Full list of author information is available at the end of the article detected until the hemodynamic decompensation stage. At this point, cardiac surgical intervention is inevitable [4]. In principle, the cardiac surgical procedures should be avoided during pregnancy, preferably at 6 weeks after delivery. However, when these pregnant women develop obvious symptoms, early intervention of cardiac surgical procedures during pregnancy is necessary. Setting up a multidisciplinary team (MDT) for management is a crucial step, which is also consistently recommended in the guidelines developed by the European Society of Cardiology (ESC). As a countrywide intensive maternal care center in China, our hospital often has such special cases of heart disease during pregnancy, but only a small number of pregnant women undergo cardiac surgery under $\mathrm{CPB}$ during pregnancy. To provide more clinical treatment experience, including preoperative, intraoperative, original author(s) and the source, provide a link to the Creative Commons licence, and indicate if changes were made. The images or other third party material in this article are included in the article's Creative Commons licence, unless indicated otherwise in a credit line to the material. If material is not included in the article's Creative Commons licence and your intended use is not permitted by statutory regulation or exceeds the permitted use, you will need to obtain permission directly from the copyright holder. To view a copy of this licence, visit http://creativecommons.org/licenses/by/4.0/. The Creative Commons Public Domain Dedication waiver (http://creativeco mmons.org/publicdomain/zero/1.0/) applies to the data made available in this article, unless otherwise stated in a credit line to the data. 
and postoperative points of concern, we reported these four cases, which successfully underwent cardiac surgery under $\mathrm{CPB}$ during pregnancy.

\section{Case report}

\section{Patient's general information}

The four patients were aged between 24 and 34 years old, with a gestational age of 23-34 weeks. And the average hospitalization time for these four patients was 34 days. Three patients had IE with vegetation formation and severe mitral valve regurgitation, which all had bacteria cultured from blood. The patient's characteristics are listed in Table 1.

\section{Cardiac surgical procedure, intraoperatory parameters and postoperative treatment management}

All these four patients underwent cardiac surgical procedure under $\mathrm{CPB}$, including three mitral valve replacement (MVR), one Bentall procedure. Two patients were performed simultaneous cardiac surgery and cesarean section, and the other two continued their pregnancies after cardiac surgery procedure. According to the particularity of the patients-pregnancy, close intraoperative monitoring was performed, such as aortic cross-clamp time, $\mathrm{CPB}$ time, $\mathrm{CPB}$ minimum temperature, $\mathrm{CPB}$ maximum flow and $\mathrm{ACT}$ value at the beginning of $\mathrm{CPB}$, as shown in Table 2. Before the beginning of CPB, we heparinized the patients to achieve an ACT above $480 \mathrm{~s}$ and maintained the ACT above $480 \mathrm{~s}$ with ACT monitoring. Of course, attention should also be paid to the treatment and management after the procedure, for example, the treatment and monitoring to fetus protection of the two patients who continued to have pregnancy after cardiac surgical procedure, the selection of anti-infective drugs, the course of anti-infective treatment and so on, which are presented in Table 3. Mode of delivery and neonatal outcomes are in Table 4.

\section{Discussion}

IE is a fatal disease, which is relatively rare in clinical, but with a high mortality and disability rate [5]. Especially in pregnant women, IE has a high incidence of adverse maternal outcomes, as well as infant loss. Treatment and management of pregnancy-related infective endocarditis should be individualized and multidisciplinary. For example, whether open heart surgery is needed, staging or concurrent surgery, the effect of $\mathrm{CPB}$ on the fetus in staging surgery, the operation sequence of concurrent surgery, and intraoperative monitoring points. Additionally, the type of heart disease, severity, cardiac function, gestational age, the wishes of the patients and their family should also be considered [6]. Currently, the experience of clinicians in the treatment of pregnancy-related IE is still insufficient. Here, we reported four cases with heart disease during pregnancy who both underwent cardiac surgical procedures under $\mathrm{CPB}$. Two of the patients underwent simultaneous cardiac surgery and cesarean section, that is cardiac surgical procedures 2 or 2.5 hours after cesarean section, and another two patients continued their pregnancies after cardiac surgery under $\mathrm{CPB}$. In the four cases, the minimum gestational age was 23 weeks and the maximum was less than 37 weeks. Three patients with IE underwent MVR, and one patient with ascending aortic aneurysm underwent Bentall surgery.

Table 1 Patient's characteristics

\begin{tabular}{|c|c|c|c|c|c|c|c|}
\hline Patient no & Age (y) & $\begin{array}{l}\text { Weeks of gestation } \\
\text { during surgery }(w)\end{array}$ & $\begin{array}{l}\text { Type of heart } \\
\text { disease }\end{array}$ & Date of admission & Date of discharge & $\begin{array}{l}\text { Time of } \\
\text { hospitalization } \\
\text { (d) }\end{array}$ & $\begin{array}{l}\text { The type of bacteria } \\
\text { (blood culture) }\end{array}$ \\
\hline 1 & 34 & 27 & $\begin{array}{l}\text { IE (Vegetation for- } \\
\text { mation, mitral valve } \\
\text { prolapse, perfora- } \\
\text { tion, and SMVR) }\end{array}$ & 2020-03-31 & 2020-05-15 & 45 & $\begin{array}{l}\text { Oral streptococcus, } \\
\text { Staphylococcus } \\
\text { Haemolyticus }\end{array}$ \\
\hline 2 & 24 & 23 & $\begin{array}{l}\text { IE (Vegetation for- } \\
\text { mation, mitral valve } \\
\text { prolapse, perfora- } \\
\text { tion, and SMVR) }\end{array}$ & 2020-06-20 & $2020-07-21$ & 31 & $\begin{array}{l}\text { Streptococcus } \\
\text { Parasanguis }\end{array}$ \\
\hline 3 & 29 & 33 & $\begin{array}{l}\text { Aneurysm of } \\
\text { ascending aorta } \\
\text { (about } 10 \mathrm{~cm} \text { in } \\
\text { diameter), SAVR }\end{array}$ & 2020-05-14 & $2020-05-29$ & 15 & - \\
\hline 4 & 28 & 34 & $\begin{array}{l}\text { IE (Vegetation for- } \\
\text { mation, mitral valve } \\
\text { prolapse, perfora- } \\
\text { tion, and SMVR) }\end{array}$ & $2021-01-26$ & 2021-03-12 & 45 & Hemostreptococcus \\
\hline
\end{tabular}


Table 2 Cardiac surgical procedure and intraoperatory parameters

\begin{tabular}{|c|c|c|c|c|c|c|c|c|}
\hline Patient no & $\begin{array}{l}\text { Therapeutic } \\
\text { schedule }\end{array}$ & $\begin{array}{l}\text { Cardiac } \\
\text { surgical } \\
\text { procedure }\end{array}$ & $\begin{array}{l}\text { Aortic cross- } \\
\text { clamp time } \\
\text { (min) }\end{array}$ & $\begin{array}{l}\text { CPB time } \\
\text { (min) }\end{array}$ & $\begin{array}{l}\text { CPB } \\
\text { maximum } \\
\text { perfusion } \\
\text { (ML/min) }\end{array}$ & $\begin{array}{l}\text { ACT value at } \\
\text { the beginning } \\
\text { of CPB (s) }\end{array}$ & $\begin{array}{l}\text { CPB } \\
\text { minimum } \\
\text { temperature } \\
\left({ }^{\circ} \mathrm{C}\right)\end{array}$ & $\begin{array}{l}\text { Average } \\
\text { temperature } \\
\text { during } \mathrm{CPB}\left({ }^{\circ} \mathrm{C}\right)\end{array}$ \\
\hline 1 & $\begin{array}{l}\text { Cardiac surgery } \\
\text { and cesarean } \\
\text { section was } \\
\text { performed in } \\
\text { stages }\end{array}$ & $M V R+T V P$ & 74 & 126 & 3.07 & 541 & 34.1 & 35.2 \\
\hline 2 & $\begin{array}{l}\text { Cardiac surgery } \\
\text { and cesarean } \\
\text { section was } \\
\text { performed in } \\
\text { stages }\end{array}$ & $M V R+T V P$ & 87 & 135 & 2.91 & 504 & 34.8 & 35.6 \\
\hline 3 & $\begin{array}{l}\text { Cardiac surgery } \\
\text { was performed } \\
\text { at the same } \\
\text { time as the } \\
\text { cesarean sec- } \\
\text { tion }\end{array}$ & $\begin{array}{l}\text { Bentall proce- } \\
\text { dure }\end{array}$ & 72 & 113 & - & 695 & 31.5 & 34.0 \\
\hline 4 & $\begin{array}{l}\text { Cardiac surgery } \\
\text { was performed } \\
\text { at the same } \\
\text { time as the } \\
\text { cesarean sec- } \\
\text { tion }\end{array}$ & $\mathrm{MVR}+\mathrm{TVP}$ & 76 & 125 & 2.80 & 481 & 34.1 & 35.6 \\
\hline
\end{tabular}

CPB, cardiopulmonary by pass; $\mathrm{ml}$, mini liter; min, minutes; MVR, mitral valve replacement; TVP, tricuspid valvuloplasty; ACT, activated clotting time; s, seconds

Table 3 Postoperative treatment management

\begin{tabular}{|c|c|c|c|c|c|c|}
\hline Patient no & $\begin{array}{l}\text { Fetus protection } \\
\text { treatment }\end{array}$ & $\begin{array}{l}\text { Postoperative fetal } \\
\text { monitoring }\end{array}$ & $\begin{array}{l}\text { Duration of fetal } \\
\text { monitoring }\end{array}$ & Anti-infective drugs & $\begin{array}{l}\text { Duration of anti- } \\
\text { infective treatment }\end{array}$ & $\begin{array}{l}\text { Maternal and fetal } \\
\text { outcomes }\end{array}$ \\
\hline 1 & $\begin{array}{l}\text { Atosiban, magnesium } \\
\text { sulfate }\end{array}$ & $\begin{array}{l}\text { FHR was moni- } \\
\text { tored by Doppler } \\
\text { ultrasound, closely } \\
\text { prenatal examination }\end{array}$ & $\begin{array}{l}\text { Until the time of } \\
\text { labor }\end{array}$ & $\begin{array}{l}\text { Vancomycin, imipe- } \\
\text { nem }\end{array}$ & 6 weeks after surgery & Alive, preterm birth \\
\hline 2 & $\begin{array}{l}\text { Atosiban, magnesium } \\
\text { sulfate }\end{array}$ & $\begin{array}{l}\text { FHR was moni- } \\
\text { tored by Doppler } \\
\text { ultrasound, closely } \\
\text { prenatal examination }\end{array}$ & $\begin{array}{l}\text { Until the time of } \\
\text { labor }\end{array}$ & $\begin{array}{l}\text { Vancomycin, mero- } \\
\text { penem }\end{array}$ & 6 weeks after surgery & Alive, term birth \\
\hline 3 & - & - & - & - & - & Alive, preterm birth \\
\hline 4 & - & - & - & $\begin{array}{l}\text { vancomycin, mero- } \\
\text { penem }\end{array}$ & 6 weeks after surgery & Alive, preterm birth \\
\hline
\end{tabular}

FHR, Fetal heart rate

Table 4 Mode of delivery and neonatal outcomes

\begin{tabular}{lll}
\hline Patient no & Mode of delivery & Neonatal outcomes \\
\hline 1 & Vaginal delivery & $\begin{array}{l}\text { The baby was delivered at } \\
36 \text { weeks gestation and } \\
\text { weighed } 2370 \mathrm{~g} \\
\text { The baby was successfully } \\
\text { delivered at } 40 \text { weeks } \\
\text { gestation, weighing } \\
2350 \mathrm{~g}\end{array}$ \\
3 & Cesarean section & $\begin{array}{l}\text { The fetus weighed } 1860 \mathrm{~g} \\
\text { The fetus weighed } 2020 \mathrm{~g}\end{array}$ \\
4 & Cesarean section &
\end{tabular}

All these four cases were mechanical valves. Cases 1 and 2 underwent staging heart surgical procedures for fetal protection due to their small gestational age. Progesterone was used to suppress uterine contractions after surgery, while magnesium sulfate and atosiban were used for fetal protection. Fetal heart rate (FHR) was closely monitored during cardiac surgery and continued until the time of labor to ensure fetal stability and to avoid premature delivery. And the department of obstetrics was also involved in the management of postoperative monitoring and treatment of the fetuses. Through follow-up, 
we learned that the pregnant woman in Case 1 delivered a baby girl naturally at 36 weeks gestation, while another pregnant woman in Case 2 delivered a baby boy by cesarean section at 40 weeks gestation. Staged surgery requires more and more complex monitoring and evaluation, including preoperative, intraoperative, and postoperative. For example, the indications and timing of surgery should be evaluated according to the patient's condition; FHR should be monitored continuously, the duration of $\mathrm{CPB}$ should be reduced, and the perfusion flow and pressure of $\mathrm{CPB}$ should be improved during the operation; anti-infective therapy should be continued until 6 weeks after operation. For these two patients who continued pregnancy after cardiac surgery, they needed a higher cardiac output to maintain a higher cardiac index (CI). After surgery, we gave them a component blood transfusion, albumin supplementation, nutritional enhancement, and vasoactive drugs to run a higher CI. Therefore, open heart surgery in pregnant women is usually avoided and ideally delayed until 6 weeks postpartum [7]. However, when pregnant women develop obvious symptoms, early cardiac surgical intervention is the best option, and heart valve replacement is the first choice. In the four cases we reported, three of the patients developed lifethreatening symptoms and the other one was a high-risk ascending aortic aneurysm. Thus, we formed the MDT, including departments of obstetrics, cardiac surgery, anesthesiology, intensive care, neonatology, and medical services, to discuss the treatment options that would be most beneficial to patients. CPB has a great influence on the fetus, the main influencing factors include the time of CPB heparinization, perfusion fluid temperature, perfusion flow and pressure, as well as maternal temperature. In the case that open heart operation is inevitable for pregnant women, anesthesia management, CPB management, intraoperative fetal monitoring and perioperative management are particularly important [8]. In the two cases reported in our report, with the cooperation of the surgeon, anesthesiologist and nurses, the operation time was only about 4 hours, which greatly reduced the time of $\mathrm{CPB}$ and kept the perfusion fluid at room temperature of $35^{\circ} \mathrm{C}$ to the greatest extent to reduce the adverse outcome of low temperature on the fetuses. The perfusion was performed with high flow, high pressure and high hematocrit, and the FHR was monitored by Doppler ultrasound throughout the operation. Fetal death most often occurs during the cooling and rewarming phases of CPB [8]. Thus, the risk of fetal death can be greatly reduced by performing the operation at room temperature and controlling the temperature changes during the diversion. In these two patients, the temperature variation during $\mathrm{CPB}$ cooling and rewarming was 34.1$36.2{ }^{\circ} \mathrm{C}$ (the average temperature was $35.2{ }^{\circ} \mathrm{C}$ ) in case 1 and $34.8-36.4{ }^{\circ} \mathrm{C}$ (the average temperature was $35.6{ }^{\circ} \mathrm{C}$ ) in case 2 . Low molecular weight heparin was used in the early stage of the operation, and warfarin was used until about one week before parturition when the condition of the pregnant women and the fetuses were stable, so that the prothrombin international ratio was maintained at 2.0-3.0. Imipenem combined with vancomycin was also used for anti-infective therapy until 6 weeks after surgery. Of course, the fetuses need to be continued to be closely monitored postoperatively. Case 3 was a patient at 33 weeks of pregnancy, diagnosed with ascending aortic aneurysm complicated with severe aortic valve insufficiency. CTA examination indicated that the dilated diameter of the ascending aorta was more than $8 \mathrm{~cm}$, and her immediate family members, her aunts and uncles, had a history of Marfan syndrome. She is at high risk during pregnancy, and early cardiac surgery intervention is needed. Cases 3 and 4 both underwent cesarean section and heart valve replacement at the same time, and both mother and fetuses survived. CPB has a greater impact on the fetus and the fetal mortality rate is high, ranging from 16 to 33\% [8]. Therefore, the study of Chandni Patel et al recommended that cesarean section be performed prior to CPB-MVR to improve fetal outcome [8]. Simultaneous cardiac surgery and cesarean section, like cases 3 and 4 in our report, should also consider the increased risk of postpartum bleeding as an important risk factor, which may cause pregnant women to lose their uterus. In the two cases we reported, we used uterine balloon tamponade and bilateral uterine artery ascending branch ligation, combined with intravenous drops of oxytocin to prevent massive postpartum hemorrhage. Replacement of heart valves 2 or 2.5 hours after a cesarean section is also a key step in reducing postpartum bleeding in pregnant women. Reducing the aortic cross-clamp time and $\mathrm{CPB}$ time also do help to reduce the risk of cardiac surgical procedures and complications in pregnant women. In these four cases we reported, anti-coagulation on $\mathrm{CPB}$ was also using activated clotting time (ACT) monitoring. ACT is considered the gold standard in monitoring anti-coagulation for CPB [9]. Bull and colleagues' study showed no development of clots in the oxygenator or circuit when ACT was maintained above $300 \mathrm{~s}$ [9]. In our study, we maintained ACT above $480 \mathrm{~s}$. After systemic heparinization, $\mathrm{CPB}$ was started after ACT reached to $480 \mathrm{~s}$. For the selection of drugs commonly used in cardiac surgery, we routinely followed the guidelines and there were no particular drugs that we had to avoid.

\section{Conclusion}

We have successfully performed cardiac surgery under $\mathrm{CPB}$ for four pregnant women with heart disease during pregnancy. Two of them were performed simultaneous 
cardiac surgery and cesarean section, and the other two continued their pregnancies after cardiac surgery. All four patients survived, both mothers and fetuses. These four cases we reported show that surgical interventions should be carried out actively and proactively for heart disease during pregnancy with obvious symptoms. Of course, we should be careful about the occurrence of postoperative complications. Collaborative management of multidisciplinary teams is a good way.

\begin{abstract}
Abbreviations
CPB: Cardiopulmonary bypass; IE: Infective endocarditis; MDT: Multidisciplinary team; SMVR: Severe mitral valve regurgitation; MVR: Mitral valve replacement; SAVR: Severe aortic valve regurgitation; TVP: Tricuspid valvuloplasty; ACT: Activated clotting time; FHR: Fetal heart rate; CT: Cardiac index; ml: Mini litre; min: Minutes; g: Gram; y: Year; w: Week; d: Day; s: Second.
\end{abstract}

\section{Acknowledgements}

The authors gratefully acknowledge the physicians involved in the treatment.

\section{Authors' contributions}

$S L$ participated in the surgeries as the chief surgeon, provided data and revised the manuscript. YY collected the data of patients, analyzed the data and wrote the manuscript. The authors read and approved the final manuscript. ZW participated in the surgeries and in the postoperative management of the patients. DC provided relevant professional support and participated in the whole treatment of patients. GW participated in the treatment of patients. GC participated in the surgeries and in the postoperative management of the patients. YP participated in the surgeries and in the whole treatment of the patients. XZ participated in the surgeries. All authors read and approved the final manuscript.

\section{Funding}

Doctoral Initiation Project of The Third Affiliated Hospital of Guangzhou Medical University.

\section{Availability of data and materials}

The data were presented in the main manuscript.

\section{Declarations}

Ethics approval and consent to participate

The ethics committee of The Third Affiliated Hospital of Guangzhou Medical University Hospital approved the study.

\section{Consent for publication}

All of the authors agree to the publication of the article.

\section{Competing interests}

The authors declare that they have no competing interests.

\section{Author details}

${ }^{1}$ Thoracic and Cardiovascular Surgery, The Third Affiliated Hospital of Guangzhou Medical University, Guangzhou, Guangdong, China. ${ }^{2}$ Obstetrics and Gynecology Department, The Third Affiliated Hospital of Guangzhou Medical University, Guangzhou, Guangdong, China.

Received: 4 July 2021 Accepted: 29 August 2021

Published online: 25 September 2021

\section{References}

1. Mahli A, Izdes S, Coskun D. Cardiac operations during pregnancy: review of factors influencing fetal outcome. AnnThorac Surg. 2000;69:1622-6.

2. Cauldwell M, Johnson M, Jahangiri M, Roos-Hesselink J. Cardiac interventions and cardiac surgery and pregnancy. Int J Cardiol. 2018;276:43-7.

3. Liu Y, Han F, Zhuang J, Liu X, Chen J, Huang H, Wang S, Zhou C. Cardiac operation under cardiopulmonary bypass during pregnancy. J Cardiothorac Surg. 2020;15:92.

4. Nguyen A, Schaff HV. Chapter 26: Cardiac surgery during pregnancy. In: Cardiac problems in pregnancy, 4th ed. 2019.

5. The Task Force for the Management of Infective Endocarditis of the European Society of Cardiology (ESC). ESC Guidelines for the management of infective endocarditis. Eur Heart J. 2015;36:3075-123.

6. Wang J, Wang A, Cui Y, Wang C, Zhang J. Diagnosis and treatment of infective endocarditis in pregnancy: a case report. J Cardiothorac Surg. 2020;15:109.

7. Nguyen A, Schaff HV. Cardiac surgery during pregnancy.

8. Patel C, Akhtar H, Gupta S, Harky A. Pregnancy and cardiac interventions: what are the optimal management options? J Card Surg. 2020;35:1589-96.

9. Shore-Lesserson L, Baker RA, Ferraris VA, Greilich PE, Fitzgerald D, Roman P, Hammon JW. The Society of Thoracic Surgeons, The Society of Cardiovascular Anesthesiologists, and The American Society of ExtraCorporeal Technology: clinical practice guidelines-anticoagulation during cardiopulmonary bypass. Ann Thorac Surg. 2018;105:650-62.

\section{Publisher's Note}

Springer Nature remains neutral with regard to jurisdictional claims in published maps and institutional affiliations.
Ready to submit your research? Choose BMC and benefit from:

- fast, convenient online submission

- thorough peer review by experienced researchers in your field

- rapid publication on acceptance

- support for research data, including large and complex data types

- gold Open Access which fosters wider collaboration and increased citations

- maximum visibility for your research: over $100 \mathrm{M}$ website views per year

At BMC, research is always in progress.

Learn more biomedcentral.com/submissions 